ЕКСПЕРИМЕНТАЛЬНА ТА КЛІНІЧНА ФАРМАКОЛОГІЯ

Recommended by Doctor of Pharmacy, professor N.M.Kononenko

UDC 616.992.282:615.371:615.015.33

\title{
THE STUDY OF THE THERAPEUTIC ACTION OF THE CELL-ASSOCIATED ANTIGENS OF CANDIDA ALBICANS AND CANDIDA TROPICALIS FUNGI
}

\author{
M.V.Rybalkin \\ National University of Pharmacy \\ Key words: candidiasis; antigen; vaccine; therapy
}

\begin{abstract}
Fungi of Candida genus are the most widespread causative agent of fungal infections. Candida causes a wide range of infections: from insignificant diseases of the skin and mucous membranes to invasion processes that can practically destroys all organs. Development of a vaccine against candidiasis is the topical issue of modern pharmacy and medicine. Suspensions of cells of Candida albicans and Candida tropicalis fungi were subjected to the action of ultrasound, then filtered through a "Vladipore" membrane MFA-MA No. 3 providing separation of the biological material with the size of $10 \mathrm{kDa}$ and its concentration. Then prefiltration and sterilizing filtration were carried out. The resulting purified antigens of Candida albicans fungi cells with the protein concentration of $3 \mathrm{mg} / \mathrm{ml}$ and Candida tropicalis with the protein concentration of $5 \mathrm{mg} / \mathrm{ml}$ were mixed in the ratio of 1:1 using a mixer with the rotation speed of $100 \mathrm{rpm}$ for $10 \mathrm{~min}$. In the experiment two-month white mice with the body weight of 18-22 $g$ were used; there were 6 animals in the control and test groups. The animals were infected intraperitoneally with the suspension of Candida albicans in the amount of $20 \mathrm{mln}$ of cells and Candida tropicalis in the amount of $60 \mathrm{mln}$ of cells in the volume of $1 \mathrm{ml}$. In 5 days the cell-associated antigens of Candida fungi in the volume of $0.2 \mathrm{ml}$ were injected intramuscularly to mice in the upper part of the rear right paw. In 14 days the procedure was repeated. The animals of the control group were injected with the sterile $0.9 \%$ isotonic saline solution. After that in 14 days the animals were examined and the results were determined. According to the research results it has been found that the cell-associated antigens of Candida albicans and Candida tropicalis provide the therapeutic effect in $100 \%$ of animals when injected intramuscularly in the volume of $0.2 \mathrm{ml}$.
\end{abstract}

Fungi of Candida genus are the most widespread causative agent of fungal infections. Candida causes a wide range of infections: from insignificant diseases of the skin and mucous membranes to invasion processes that can practically destroys all organs $[1,3,7]$. Such wide range of infections requires also a wide range of diagnostic and therapeutic strategies.

According to many researchers the use of vaccines for treating candidiasis is considered to be a promising direction. Such studies are carried out actively both on the territory of the former Soviet Union, and in Europe and America [2, 4, 6, 8]. It should be noted that currently no domestic vaccine is produced in Ukraine and no imported vaccines have been registered. Therefore, development of a vaccine against candidiasis is the topical issue of modern pharmacy and medicine.

Different researchers propose several variants of vaccines, but they have no consensus. Subunit vaccines are one of the varieties of vaccines. They consist of the antigen fragments that are capable to provide the adequate immune response. These vaccines can be presented both as particles of microbes and as those obtained in the labo- ratory conditions by using genetic engineering technologies $[5,9,10]$. The examples of subunit vaccines with the fragments of microorganisms used are vaccines against Streptococcus pneumoniae and meningococcus type A.

Multivalent or assosiated vaccines are used for simultaneous immunization against a number of infections. They can include both homogeneous antigens (for example, anatoxin), and antigens of different nature (particle and molecular, living and dead antigens). The example of the associated vaccine of the first type can be sexta-anatoxin against tetanus, gas gangrene and botulism, of the second type - DTP vaccine, which includes tetanus and diphtheria toxoids, pertussis particle vaccine. The living multivalent associated polio vaccine contains living vaccines of polio virus types I, II, III strain.

The associated vaccine contains antigens in doses that do not cause mutual competition in order to form the immunity to all antigens including in the composition of the vaccine.

As it has been shown in the previous studies, the cell-associated antigens of Candida albicans fungi with the protein concentration of $3 \mathrm{mg} / \mathrm{ml}$ and Candida tropi- 
calis with the protein concentration of $5 \mathrm{mg} / \mathrm{ml}$ in the ratio of 1:1 when injected intramuscularly in the volume of $0.2 \mathrm{ml}$ to healthy mice can stimulate the immunity formation against candidiasis, i.e. after immunization the animals do not develop candidiasis when infected by Candida fungi. At present it is necessary to check whether the extracts of the cell-associated antigens of Candida albicans and Candida tropicalis fungi possess the therapeutic effect in the given dose, namely if when administered intramuscularly to mice with candidiasis the suspension is able to stimulate formation of the immunity against candidiasis and provide the further recovery of the infected mice.

The aim of the work is to study the therapeutic effect of the cell-associated antigens of Candida albicans and Candida tropicalis fungi.

\section{Materials and Methods}

All studies were conducted in the laminar box maintaining aseptic conditions. To perform the inactivation of the fungal cells of Candida albicans of CCM 335-867 strain and Candida tropicalis of ATTC 20336 strain, they were preliminary cultivated according to the scheme in the test-tubes on the Sabouraud agar separately at $25 \pm 2{ }^{\circ} \mathrm{C}$ within 48 hours and the fungal cells were washed with $10 \mathrm{ml}$ of the sterile $0.9 \%$ isotonic saline solution. The suspensions of the fungal cells of Candida albicans and Candida tropicalis obtained separately were trasferred to the flasks with the Sabouraud agar and incubated at $25 \pm 2{ }^{\circ} \mathrm{C}$ within 6 days and washed the fungal cells with $25 \mathrm{ml}$ of the sterile $0.9 \%$ isotonic saline solution. The microbiological purity of the suspension of the fungal cells of Candida albicans and Candida tropicalis was determined visually and by the method of microscopy. Then centrifugation with the rotation speed of $3000 \mathrm{rpm}$ was conducted for $10 \mathrm{~min}$. The precipitate of the fungi cells obtained was diluted with the sterile $0.9 \%$ isotonic saline solution to $(8.5-9) \times 10^{8}$ in $1 \mathrm{ml}$, and the suspensions were standardized by fungal count in Goryaev chamber.

The suspensions of cells of Candida albicans and Candida tropicalis fungi in the volume of $10 \mathrm{ml}$ were subjected to the action of ultrasound for destruction of the fungal cells on an UZUU-21 device at the frequency of $22 \mathrm{kHz}$, the intensity of $5 \mathrm{~W} / \mathrm{cm}^{2}$ and at the temperature of $25 \pm 2^{\circ} \mathrm{C}$ for $15 \mathrm{~min}$. All the time the temperature of $25 \pm 2^{\circ} \mathrm{C}$ was controlled with the help of ultrasonication of the suspensions of cells and maintained by adding a cold water into the surrounding container. Then there was filtration through a "Vladipore" membrane MFA-MA No.3 providing separation of the biological material with the size of $10 \mathrm{kDa}$ and its concentration. The filtrate obtained was presented by the mixture of polypeptides and polysaccharides. In each case the protein content was determined according to the requirements of the State Pharmacopoeia of Ukraine (SPhU). Then prefiltration using filters with the pore diameter of $0.45 \mu \mathrm{m}$ and sterilizing filtration using filters with the pore diameter of $0.22 \mu \mathrm{m}$ were carried out.

We take into account the fact that proteins and polysaccharides possessing the antigenic properties are in the composition of the cell extract of Candida fungi. According to the requirements of the SPhU determination of the active substance in such case is conducted by the substance, which possesses the most expressed antigenic properties, i.e. by protein.

The therapeutic effect of the cell-associated antigens of Candida albicans and Candida tropicalis fungi was investigated in healthy two-month white mice with the body weight of 18-22 g. There were 6 animals in the control and test groups; they were kept in the same conditions on a standard diet. Before the research the animals acclimatized themselves under experimental room conditions. The animals were infected intraperitoneally with the suspension of Candida albicans fungi of CCM 335-867 strain in the amount of $20 \mathrm{mln}$. of cells and Candida tropicalis of ATTC 20336 strain in the amount of $60 \mathrm{mln}$. of cells in the volume of $1 \mathrm{ml}$. In 5 days the cell-associated antigens of Candida albicans fungi with the protein concentration of $3 \mathrm{mg} / \mathrm{ml}$ and Candida tropicalis with the protein concentration of $5 \mathrm{mg} / \mathrm{ml}$ in the ratio of $1: 1$ with the volume of $0.2 \mathrm{ml}$ were injected intramuscularly to mice in the upper part of the rear right paw. The animals of the control group were injected with the sterile $0.9 \%$ isotonic saline solution. After that in 14 days the animals were examined and the results were determined.

The test results were considered according to the number of various manifestations of the disease and were estimated by the following scheme: $(-)-$ the absence of manifestations of the disease; a mild form of the disease $(+)$ - unkempt appearance, refusal to eat, the body weight loss, dysfunctions of the excretory organs; a moderate form of the disease $(++)$ - adynamia, unkempt appearance, refusal to eat, the body weight loss, contractures of the neck muscles, the lateral location of the body, dysfunctions of the excretory organs, during the autopsy when examining the mucous membranes of natural orifices the signs of pathological processes, plating of fungi with faeces were revealed; an advanced form of the disease $(+++)$ - adynamia, unkempt appearance, refusal to eat, the body weight loss, contractures of the neck muscles, paralysis of the limbs, convulsions, the lateral location of the body, dysfunctions of the excretory organs, when examining the mucous membranes of natural orifices, internal organs of the animals the signs of such pathological processes as microabscesses in the renal cortical layer, lungs, spleen, liver, etc., isolation of retrocultures of fungi from the animals' organs were revealed.

\section{Results and Discussion}

After infection of the animals according to the scheme described above they were observed within 5 days. Such signs of disease as unkempt appearance, refusal to eat, the body weight loss, dysfunctions of the excretory organs began to exhibit in the infected animals in a day. The manifestations of infection found corresponded to the mild form of the disease $(+)$. On the 4-5-th day the signs of the disease were intensified in some animals; they were adynamia, unkempt appearance, refusal to eat, the body weight loss, contractures of the neck muscles, 
Table

The study of the therapeutic effect of the cell-associated antigens of Candida albicans and Candida tropicalis fungi

\begin{tabular}{|c|c|c|c|}
\hline $\begin{array}{c}\text { Cell-associated antigens } \\
\text { of Candida albicans and } \\
\text { Candida tropicalis fungi }\end{array}$ & \multicolumn{2}{|c|}{ Control } \\
\hline $\begin{array}{c}\text { After } \\
\text { infection }\end{array}$ & $\begin{array}{c}\text { After the } \\
\text { second } \\
\text { injection }\end{array}$ & $\begin{array}{c}\text { After } \\
\text { infection }\end{array}$ & $\begin{array}{c}\text { After the } \\
\text { second } \\
\text { injection }\end{array}$ \\
\hline++ & - & + & ++ \\
\hline+ & - & ++ & +++ \\
\hline++ & - & + & ++ \\
\hline+ & - & ++ & +++ \\
\hline++ & - & + & +++ \\
\hline++ & - & ++ & +++ \\
\hline
\end{tabular}

Note: - absence of the disease, +- a mild form of the disease, ++ a moderate form of the disease,++ an advanced form of the disease.

the lateral location of the body, dysfunctions of the excretory organs, when examining the mucous membranes of natural orifices the signs of pathological processes, plating of fungi with faeces were revealed. The manifestations of infection found corresponded to the moderate form of the disease $(++)$.

After double injection of the associated antigens Candida albicans and Candida tropicalis fungi or the sterile $0.9 \%$ isotonic saline solution the animals were carefully observed. In the control group, which was immunized with the sterile $0.9 \%$ isotonic saline solution, manifestations of disease intensified in 5-14 days. Adynamia, unkempt appearance, refusal to eat, the body weight loss, contractures of the neck muscles, paralysis of the limbs, convulsions, the lateral location of the body, dysfunctions of the excretory organs were registered. During the autopsy after the experiment when examining the mucous membranes of natural orifices, internal organs of the animals the signs of such pathological processes as microabscesses in the renal cortical layer, lungs, spleen, liver, etc., as well as isolation of retrocultures of fungi from the animals' organs were revealed.

The therapeutic effect of the cell-associated antigens of Candida albicans and Candida tropicalis fungi started to appear in 5-14 days after the first injection. In the animals adynamias, contractures of the neck muscles, the lateral location of the body, plating fungi with faeces were weakened or disappeared. In 5-14 days after the repeated introduction of the cell-associated antigens of Candida fungi the further improvement and recovery of the animals were observed. The appearance of the animals improved, the appetite appeared, the body weight increased, dysfunctions of the excretory organs disappeared.

The therapeutic effect of the cell-associated antigens of Candida albicans fungi with the protein concentration of $3 \mathrm{mg} / \mathrm{ml}$ and Candida tropicalis with the protein concentration of $5 \mathrm{mg} / \mathrm{ml}$ in the ratio of $1: 1$ was $100 \%$. The research results are given in Table.

Thus, the cell-associated antigens of Candida albicans and Candida tropicalis fungi have the immunogenic and therapeutic activity, as well as the antigens of Candida albicans and Candida tropicalis fungi cells separately. However, in case of the cell-associated antigens of Candida albicans and Candida tropicalis fungi we inject at once only one vaccine against two species of fungi - Candida albicans and Candida tropicalis. Therefore, the cell-associated antigens of fungi are more promising than the individual antigens of fungi cells.

In the future, it is planned to select experimentally excipients that can provide the long-term storage of the activity of the vaccine developed.

\section{CONCLUSIONS}

According to the research results it has been found that the cell-associated antigens of Candida albicans with the protein concentration of $3 \mathrm{mg} / \mathrm{ml}$ and Candida tropicalis with the protein concentration of $5 \mathrm{mg} / \mathrm{ml}$ in the ratio of $1: 1$ provide the therapeutic effect in $100 \%$ of animals when injected intramuscularly in the volume of $0.2 \mathrm{ml}$.

Therefore, the cell-associated antigens of Candida albicans and Candida tropicalis fungi obtained possess the therapeutic activity and are a subunit combined vaccine of Candida albicans and Candida tropicalis fungi.

\section{REFERENCES}

1. Миленина О.Е., Кравиов Э.Г., Кузьменко Л.Г. и др. // Проблемы мед. микол. - 2006. - Т. 8, №3. - С. 14-16.

2. Пат. 2352355 РФ, МПК7 А 61 К 39/00, А 61 Р 31/00. - 2007139596/13. - Заявл.: 25.10.2007. Опубл.: 25.10.2007.

3. Резниченко Н.А. // Здоровье женщины. - 2006. - №3 (27). - C. 53-55.

4. Aditi Grover, Bhandari B.S., Rai Nishant, Pramesh C. Lakhera // Biotechnol. International. - 2010. - Vol. 3, №1. - P. 4-17.

5. Carvalho A. // Front. Microbiol. - 2012. - Vol. 3. - P. 1-9.

6. Cassone A. // Nature Reviews Microbiol. - 2013. - Vol. 11. - P. 884-891.

7. Diekema D., Arbefeville S., Boyken L. et al. // Diagn. Microbiol. Infect. Dis. - 2012. - Vol. 73. - P. 45-48.

8. Han Y., Rhew K.Y. // Arch. Pharm. Res. - 2012. - Vol. 35. - P. 2021-2027.

9. Nabel G.J. // N. Eng. J. Med. - 2013. - Vol. 6, №368. - P. 551-60.

10. Skibinski A.G., David and Barbara C. Baudner, Singh Manmohan, O'Hagan T. Derek // Glob. Infect. Dis. 2011. - Vol. 3, №1. - P. 63-72. 


\section{ДОСЛІДЖЕННЯ ТЕРАПЕВТИЧНОЇ ДІЇ АСОЦІЙОВАНИХ АНТИГЕНІВ КЛІТИН ГРИБІВ CANDIDA ALBICANS TA CANDIDA TROPICALIS М.В.Рибалкін \\ Ключові слова: кандидамікоз; антиген; вакцина; терапія}

Candida викликає широкий діапазон інфрекцій: від незначних захворювань шкіри та слизових оболонок до інвазійних процесів, які можуть вражати практично усі органи. Розробка вакцини проти кандидамікозу є актуальним питанням сучасної фрармації та медицини. Суспензії клітин грибів Candida albicans ma Candida tropicalis піддавали дї ультразвуку, фрільтрували через мембрану «Владипор» МФА-МА №3 з розміром 10 кДа, проводили попередню та стерелізуючу фрільтрацію. Одержані стерильні очищені антигени клітин грибів Candida albicans 3 концентрацією білка 3 мг/мл ma Candida tropicalis з концентрацією білка 5 ме/мл змішували у співвідношенні 1:1 за допомогою мішалки. У досліді використовували двомісячних білих мишей масою 18-22 г по 6 тварин у контрольних та дослідних групах. Тварин заражали внутрішньоочеревинно суспензією грибів Candida albicans 20 млн клітин ma Candida tropicalis 60 млн клітин в об'ємі 1 мл. Через 5 діб мишам внутрішньом'язово вводили асоційовані антигени клітин грибів Candida у об'ємі по 0,2 мл. Через 14 діб повторювали цю процедуру. Тваринам у контрольній групі вводили стерильний ізотонічний розчин 0,9\% натрію хлориду, після чого через 14 діб проводили огляд тварин та визначали результати. За результатами досліджень встановлено, що одержані асоційовані антигени клітин грибів Candida забезпечують терапевтичний ефект у 100\% тварин при внутрішньом'язовому введенні в об'ємі 0,2 мл.

\section{ИЗУЧЕНИЕ ТЕРАПЕВТИЧЕСКОГО ДЕЙСТВИЯ АССОЦИИРОВАННЫХ АНТИГЕНОВ КЛЕТОК ГРИБОВ СANDIDA ALBICANS И CANDIDA TROPICALIS Н.В.Рыбалкин \\ Ключевые слова: кандидамикоз; антиген; вакцина; терапия}

Candida вызывает широкий диапазон инфекций: от незначительных заболеваний кожи и слизистых оболочек до инвазионных процессов, которые могут поражать практически все органы. Разработка вакцины против кандидамикоза является актуальным вопросом современной фрармации и медицины. Суспензии клеток грибов Candida albicans u Candida tropicalis подвергали действию ультразвука, фильтровали через мембрану «Владипор» МФА-МА №3 с размером пор 10 кДа, проводили предварительную и стерилизующую фильтрацию. Полученные стерильные очищенные антигены клеток грибов Candida albicans $c$ концентрацией белка 3 мг/мл и Candida tropicalis с концентрацией белка 5 мг/мл смешивали в соотношении 1:1 с помощью мешалки. В эксперименте использовали двухмесячных белых мышей массой 18-22 г по 6 животных в контрольной и исследуемой группах. Животных заражали внутрибрюшинно суспензией грибов Candida albicans 20 млн клеток и Candida tropicalis 60 млн клеток в объеме 1 мл. Через 5 суток мышам внутримышечно вводили ассоциированные антигены клеток грибов Candida в объеме 0,2 мл. Через 14 суток повторяли эту процедуру. Животным в контрольной группе вводили стерильный изотонический раствор 0,9\% натрия хлорида. После чего через 14 суток проводили осмотр животных и определяли результаты. Согласно результатам исследования установлено, что полученные ассоциированные антигены клеток грибов Candida обеспечивают терапевтический эфрфект у 100\% животных при внутримышечном введении в объеме 0,2 мл. 